\title{
Environmental and Economic Efficiency of Comprehensive Technology of Sulfur Oxides, Nitrogen Oxides and Mercury Removal from Flue Gases
}

\author{
Svetlana Grigashkina ${ }^{1 *}$, Tatyana Galanina ${ }^{1}$, Vladimir Mikhailov ${ }^{1}$, Tatyana Koroleva ${ }^{1}$, \\ Evgeniya Trush $^{2}$ \\ ${ }^{1}$ T.F. Gorbachev Kuzbass State Technical University, 28 Vesennyaya st., 650000, Kemerovo, Russia \\ ${ }^{2}$ Tomsk State University of Architecture and Building, 2 Solyanaya Sq., 634003, Tomsk, Russia
}

\begin{abstract}
The article reviews the issues of environmental and economic efficiency of the comprehensive technology of removing sulphur and nitrogen oxides and mercury from flue gases. The purpose of the study is to justify the choice of the methods for the analysis of environmental and economic effectiveness of the designed air protection activities and to perform a number of calculations. The article analyses main processing methods for reducing the concentration of sulfur and nitrogen oxides in the flue gases from the combustion of coal fuels, thus generating maximum ecological and economic benefits. The main result of the work is development of the adapted system of technical, environmental and economic indicators characterizing the high efficiency of the proposed technical solutions. The results of the study can be recommended to heating enterprises in support of effective environment-friendly management decisions justifying implementation of appropriate flue gas cleaning technologies.
\end{abstract}

\section{Introduction}

The problem of air pollution is the most relevant for such countries as Russia and China with a high concentration of thermal power plants. This situation is largely due to the use of coal-fired CHP (combined heat and power), having a high degree of versatility, on the one hand, and, on the other hand, such a disadvantage, as high physical and moral wear of the equipment, as well as significant environmental pollution. Currently increasing production growth rates and the tightening of environmental legislation $[1,2,3]$ generate new requirements for the equipment used in the thermal power stations, in particular, special attention is paid to employed boiler plants which must comply with the new requirements related to the provision of permissible values of emission of some combustion products of solid, liquid and gaseous fuels. Fuel combustion at CHP is linked to generation of combustion products containing fly ash, sulfur dioxide, nitrogen oxides, and other products of incomplete combustion. In general, in the Russian cities the average of the maximum measured concentrations of impurities other than sulfur dioxide and nitrogen oxide exceed $1 \mathrm{MAC}$, the highest level of air pollution occurs in cities located on the territory of the Siberian and Ural

*Corresponding author: grigashkina_si@mail.ru 
Federal Districts.

A similar situation exists in China, where the main cause of pollution of the atmosphere is a low level of energy product treatment. Another problem is also connected to moral and physical wear and tear of the equipment of enterprises. Furthermore, coal produced in China has a high sulfur content. Cities located in the basins poorly permeable to winds are particularly vulnerable to air pollution (Chongqing, Wuhan, Beijing, Nanjing and others) [4, 5].

The reviewed situation characterizes the significant environmental problems requiring immediate solutions:

- Reduction of emissions amount;

- Introduction of new environmentally clean technologies, including the best available techniques (BAT);

- Minimization of the impact of the anthropogenic complex on the environment;

- Restoration of the natural balance.

The scientific novelty of the work lies in the theoretical and practical justification of environmental and economic efficiency of the comprehensive technology developed by a group of scientists from KuzSTU for effective removal of sulfur oxides, nitrogen and mercury from flue gases. The practical result of the work relates to the possibility of its implementation at coal-fired CHP and district power plants of the Kemerovo region and other regions which adversely affect the environment.

\section{Results and Discussion}

The analysis of scientific, technical and patent literature has shown that in order to reduce the content of sulfur and nitrogen oxides in the flue gases from the combustion of coal fuels three main technological methods are used $[6,7,8,9,10,11,12,13]$ :

- Reduction of the concentration of sulfur in the original coal coming to power and steam stations;

- Reduction of the concentration of sulfur oxides formed during combustion of coal fuel containing sulfur by introducing Sulphur Capture Agents (SCA) in the combustion zone;

- Reduction of the concentration of sulfur and nitrogen oxides in flue gases by means of purification of the latter using a number of known methods, most effective of which are methods of sorption and catalytic purification of flue gases.

Despite the fact that all the techniques described are effective methods, each of them used alone does not achieve complete cleaning. KuzSTU scientists have developed a new technology based on a comprehensive efficient cleaning of coal-fired thermal power plants flue gases of sulfur oxides, nitrogen oxides, and mercury.

This technology has the following advantages:

- $\quad$ Possibility of burning both coal and coal-water fuel;

- Possibility of differentiating the ways of coal fuel combustion (in a swirl burner, in a compact bed, in a fluidized bed);

- Introducing SCA to the combustion zone as part of the fuel or separately;

- Removing harmful impurities from the flue gases as part of the furnace and in the flue gas and smoke path;

- Performing a comprehensive removal of flue gases by several methods:

1) desulphurization at the coal fuel combustion stage, including SCA feed to the fuel during its preparation for combustion;

2) SCA feed directly in the burner in accordance with the individual scheme;

3) catalytic purification of waste gases from sulfur and nitrogen oxides;

4) absorption cleaning of flue gases from sulfur oxides, nitrogen oxides and mercury.

This comprehensive technology allows an increase of the cleaning efficiency up to $90 \%$ and significantly reduces the burden on the environment.

In order to assess the negative impact, the ecological and economic parameters [14-17] are used, of which the economic damage being the most crucial. The economic damage of air pollution ( $\left.\mathrm{E}_{\mathrm{dap}}\right)$ is determined by the following formula:

$$
E_{\text {dap }}=\gamma_{s} \cdot R_{\text {ind }} \cdot C_{\text {esa }} \cdot M r \text {, roubles, }
$$


where $\gamma_{\mathrm{s}}$ - the specific economic damage from air pollution of one specific tonne of pollutants equivalent, 47.5 RUB./sp.t.; $\mathrm{R}_{\text {ind }}$ - indexation rate; $\mathrm{C}_{\mathrm{esa}}$ - coefficient of ecological situation for atmospheric air (it is differentiated by environmental elements and by regions, for Kemerovo region it is 1.44); $\mathrm{M}_{\mathrm{r}}$ - reduced mass of the annual emission of harmful substances into the atmosphere, sp.t./year. $M_{r}$ is calculated by the formula:

$$
M_{r}=\sum_{i=1}^{n} m_{i} \cdot A_{i},
$$

where $m_{i}$-actual mass of $\mathrm{i}$ - air pollutant, $\mathrm{t} ; i$ - type of pollutant; $n$ - total quantity of pollutants; $A_{i}$ - indicator of relative hazard of $i$-th pollutant (sp.t./t) that is determined by the formula 3:

$$
A_{i}=1 / A D M_{c i} \text {, }
$$

where $A D M_{c i}$ - average daily maximal allowable concentration of $i$-th air pollutant, $\mathrm{mg} / \mathrm{m}^{3}$.

The simplified calculation of economic efficiency of environment protection activities (without time factor) is made by the formula:

$$
R=\Delta P-C_{r},
$$

where $R$ - net economic effect from implementation of an environment protection activity, RUB.; $\Delta P$ - economic result of environment protection activities, RUB.; $C_{r}-$ reduced costs of implementation of the environment protection activity, RUB.

$$
\triangle P=P_{d}+A I \text {, }
$$

where $P_{d}$ - prevented damage, RUB.; $A I$ - additional income (increased income based on improved technical and economic indicators, including decrease in pollution charge), RUB.;

$P_{d a}$ is calculated by the upgraded formula 1 :

$$
P_{d a}=\gamma_{\mathrm{s}} \cdot R_{\text {ind }} \cdot C_{\text {esa }} \cdot \Delta M_{r} \text {, roubles }
$$

where $P_{d a}$ - prevented economic damage from air pollution, RUB.; $\Delta M_{r}-$ change in the reduced mass of annual pollutant emission, sp.t./year, that is determined by the formula:

$$
\Delta M_{r}=\sum_{i=1}^{n} \Delta m_{i} \cdot A_{i},
$$

where $\Delta m_{i}$ - change (decrease) in the actual mass of $\mathrm{i}$ - air pollutant, $\mathrm{t}$, that is calculated by the formula:

$$
\Delta m_{i}=\mathrm{m}_{\mathrm{i} 1}-\mathrm{m}_{\mathrm{i} 2},
$$

where $\mathrm{m}_{\mathrm{i} 1}, \mathrm{~m}_{\mathrm{i} 2}$ - actual masses of $\mathrm{i}$ - air pollutant, respectively, before and after implementation of an environment protection activity, $\mathrm{t}$.

$C_{r}$ is determined by the formula:

$$
C_{r}=C O_{c}+C I \cdot E_{p t i}
$$

where $\mathrm{CO}_{c}$ - current and operating costs of environment protection activity implementation, RUB., $C I$ - capital investment in the environment protection activity, RUB.; $E_{p t i}$ - profit-toinvestment ratio which is recommended to be taken equal to 0.15 .

To estimate the prevented economic damage as a result of implementation of the comprehensive flue gas cleaning system, Table 1 shows the calculation of the change in the reduced mass of air pollution for power plants with capacity of $75 \mathrm{MW}$ and $325 \mathrm{MW}$. For ease of notational convenience, the following abbreviations are taken: SCA - cleaning method using Sulphur capture agent; CC catalytic cleaning; AC - absorption cleaning.

Based on the data presented in Table 1, the prevented economic loss was calculated using formula 6 comprising 184,150 thousand RUB. for 75 MW power plant, and 797,974 thousand RUB. for 325 MW power plant.

Table 2 shows the calculation of the economic benefit from implementation of the comprehensive environment protection activity on flue gas cleaning.

Table 2 shows the high value of the potential additional income obtained as a result of calculation of pollution charge reduction (over 2 million RUB. for $75 \mathrm{MW}$ power plant and about 10 million RUB. for a $325 \mathrm{MW}$ power plant).

Based on the data presented in Table 2, the economic effect of the environment protection activity on flue gas cleaning was calculated by formulae 4 and 9 for power plants of various capacities shown in Table 3. 
Table 1. Calculation of changes in the reduced mass of air pollution for power plants of various capacities

\begin{tabular}{|c|c|c|c|c|c|c|}
\hline \multirow[t]{2}{*}{ Indicators } & \multicolumn{3}{|c|}{75 MW } & \multicolumn{3}{|c|}{$325 \mathrm{MW}$} \\
\hline & SCA & $\mathrm{CC}$ & AC & SCA & $\mathrm{CC}$ & AC \\
\hline \multirow[t]{2}{*}{ Pollutant } & \multirow[b]{2}{*}{$\mathrm{SO}_{2}$} & $\mathrm{SO}_{2}$ & $\mathrm{SO}_{2}$ & \multirow{2}{*}{$\mathrm{SO}_{2}$} & $\mathrm{SO}_{2}$ & $\mathrm{SO}_{2}$ \\
\hline & & $\mathrm{NO}_{2}$ & $\mathrm{Hg}$ & & $\mathrm{NO}_{2}$ & $\mathrm{Hg}$ \\
\hline \multirow[t]{2}{*}{$\mathrm{m}_{\mathrm{il}}, \mathrm{t} /$ year } & \multirow{2}{*}{52500} & 15.750 & 1575 & \multirow{2}{*}{227.500} & 68,250 & 6825 \\
\hline & & 143 & - & & 620 & - \\
\hline \multirow[t]{2}{*}{$\mathrm{m}_{\mathrm{i} 2}, \mathrm{t} /$ year } & \multirow{2}{*}{15750} & 1575 & 78,75 & \multirow{2}{*}{68.250} & 6825 & 341.25 \\
\hline & & 14.3 & - & & 62 & - \\
\hline \multirow[t]{2}{*}{$\Delta \mathrm{m}_{\mathrm{i}}, \mathrm{t} /$ year } & \multirow{2}{*}{36750} & 14.175 & 1496.25 & \multirow{2}{*}{159.250} & 61.425 & 6483.75 \\
\hline & & 128.7 & 0.00625 & & 558 & 0.00625 \\
\hline \multirow{2}{*}{$\begin{array}{l}A D M_{c i}, \\
\mathrm{mg} / \mathrm{m}^{3}\end{array}$} & \multirow{2}{*}{0,05} & 0.05 & 0.05 & \multirow{2}{*}{0.05} & 0.05 & 0.05 \\
\hline & & 0.04 & 0.0003 & & 0.04 & 0.0003 \\
\hline \multirow[b]{2}{*}{$A_{i}$, sp.t/t } & \multirow[b]{2}{*}{20} & 20 & 20 & \multirow[b]{2}{*}{20} & 20 & 20 \\
\hline & & 25 & 3333.3 & & 25 & 3333.3 \\
\hline \multirow{2}{*}{$\begin{array}{c}\Delta M_{r}, \\
\text { Sp.t./year }\end{array}$} & \multirow{2}{*}{735000} & 283500 & 29.925 & \multirow{2}{*}{3185000} & 1228500 & 129.675 \\
\hline & & 3217.5 & 20.8 & & 13.950 & 20.8 \\
\hline $\begin{array}{l}\Delta M \text {, total, } \\
\text { Sp.t./year }\end{array}$ & \multicolumn{3}{|c|}{1051663.3} & \multicolumn{3}{|c|}{4557145.8} \\
\hline
\end{tabular}

Table 2. Calculation of the economic benefit from implementation of environment protection activity

\begin{tabular}{|c|c|c|c|}
\hline $\begin{array}{c}\text { Heating capacity of } \\
\text { power plant }\end{array}$ & $P_{d}$, thous. RUB. & $A I$, thous. RUB. & $\Delta \mathrm{P}$, thous. RUB. \\
\hline $75 \mathrm{MW}$ & 184,150 & 2297 & 186,447 \\
\hline $325 \mathrm{MW}$ & 797,974 & 9959 & 807,933 \\
\hline
\end{tabular}

Table 3. Calculation of the economic effect of the environment protection activity on flue gas cleaning

\begin{tabular}{|c|c|c|c|c|c|}
\hline $\begin{array}{c}\text { Heating capacity of } \\
\text { power plant }\end{array}$ & $\begin{array}{c}\Delta \text { P, thous. } \\
\text { RUB. }\end{array}$ & $\begin{array}{c}\text { CI, thous. } \\
\text { RUB. }\end{array}$ & $\begin{array}{c}\text { C, thous. } \\
\text { RUB. }\end{array}$ & $\begin{array}{c}C_{r}, \text { thous. } \\
\text { RUB. }\end{array}$ & $\begin{array}{c}R, \\
\text { thous.RUB. }\end{array}$ \\
\hline $75 \mathrm{MW}$ & 186.447 & 119.032 & 137.695 & 155.549 & 30.898 \\
\hline $325 \mathrm{MW}$ & 807.933 & 419.117 & 437.023 & 499.891 & 308.042 \\
\hline
\end{tabular}

Table 3 shows that the net economic effect from the developed comprehensive technology ensuring decrease in the concentration of sulphur oxides, nitrogen oxides and mercury in the gas emissions of coal-fired CHPs of $75 \mathrm{MW}$ and $325 \mathrm{MW}$ amounts, respectively, to 30.898 thousand RUB. and 308.042 thousand RUB.

\section{Conclusion}

The study of environmental and economic efficiency of the comprehensive purification technology for thermal power plants flue gases led to the following conclusions:

- The environmental degradation in China and Russia caused by air pollution by thermal power plants was analysed;

- The priority environmental problems requiring immediate solutions were identified; 
- The scientific, technical and patent literature was analysed in order to study the technology aimed at reducing the concentration of sulfur oxides, nitrogen oxides and mercury in the flue gases from combustion of coal fuel;

- The main advantages of the proposed treatment technology were formulated;

- The techniques for calculation of basic ecological and economic indicators and for assessment of the cost-effectiveness of environmental protection measures were selected;

- The calculation of basic ecological and economic indicators characterizing the ecological and economic efficiency of the proposed measures on flue gas cleaning was performed;

- The use of the proposed three-stage technology ensuring the maximum degree of flue gas purification for similar objects of heating power industry was justified.

\section{References}

1. E.V. Ryumina, A.M. Anikina, Studies on Russian Economic Development 18, 5 (2007)

2. V.M. Tumin, A.G. Koryakov, E.P. Nikiforova, World Applied Sciences Journal 25, 6 (2013)

3. A.I. Shinkevich, A.A. Lubnina, A.G. Koryakov, V.G. Mikhailov, E.L. Vodolazhskaya, International Review of Management and Marketing 6, 2 (2016)

4. http://www.iiav.org/archives_icsv_last/2014_icsv21/content/papers/papers/full_paper_ 600_20140314144048495.pdf.

5. http://english.mep.gov.cn/News_service/news_release/201602/t20160219_330460.htm

6. Z.O. Siagi, M. Mbrawa, R\&D Journal of the SOuth African Institution of Mechanical Engineering 1 (2008)

7. I.M. Zasypkin, V.I. Murko, V.I. Fedyaev, M.P. Baranova, Therm. Science 16, 4 (2012)

8. N.V. Shikina, S.R. Khairulin, N.A. Rudina, T.N. Teryaeva, E.S. Mikhailova, Z.R. Ismagilov, Eurasian Chemico-Technological Journal 17, 2 (2015)

9. Z.R. Ismagilov, M.A. Kerzhentsev, S.A. Yashnik, S.R. Khairulin et al., Eurasian Chemico-Technological Journal 17, 2 (2015)

10. V.I. Murko, V.I. Fedyaev, V.I. Karpenok, I.M. Zasypkin, Yu.A. Senchurova, A. Riesterer, Thermal Science 19, 1 (2015)

11. Z.R. Ismagilov, N.V. Shikina, N.A. Rudina, V.A. Ushakov, R.R. Potokina, T.N. Teryaeva, Solid Fuel Chemistry 49, 4 (2015)

12. V.I. Murko, V.I. Karpenok, Yu.A. Senchurova, V.A. Khyamyalyainen, O.V. Tailakov, Coal in the 21st Century: Mining, Processing and Safety (2016)

13. N.V. Shikina, O.V. Tailakov, Z.R. Ismagilov, Coal in the 21st Century: Mining, Processing and Safety (2016)

14. T.V. Galanina, M.I. Baumgarten, V.G. Mikhailov, T.G. Koroleva, G.S. Mikhailov, IOP Conf. Series: Earth and Environmental Science 50, 012030 (2017)

15. S.A. Zhironkin, A.A. Khoreshok, M.A. Tyulenev, G.A. Barysheva, M.C. Hellmer, IOP Conf. Ser.: Mater. Sci. Eng., 142, 012127 (2016)

16. V.G. Mikhailov, G.S. Mikhailov, A.G. Koryakov, Journal of Mining Science 51, 5 (2015)

17. N.N. Golofastova, V.G. Mikhailov, T.V. Galanina, Coal in the 21 st Century: Mining, Processing and Safety (2016) 